\title{
The Action of Streptonigrin on Bacterial DNA Metabolism and on Induction of Phage Production in Lysogenic Bacteria'
}

\author{
MYRON LEVINE AND MARCENE BORTHWICK \\ Department of Human Genetics, University of Michigan Medical School, \\ Ann Arbor, Michigan
}

Accepted August 5, 1963

\begin{abstract}
Net DNA synthesis is preferentially inhibited in Salmonella typhimurium by treatment with the antibiotic streptonigrin. As with other agents that affect DNA synthesis, short exposures to streptonigrin result in excellent induction of phage production in inducible lysogenic bacteria. Moreover, these cells produce good yields of active phage when maintained in the presence of the inhibitor until lysis oceurs. The characteristics of a cell line which shows a high degree of resistance to the antibiotic are described.
\end{abstract}

\section{INTRODUCTION}

Agents that act as inducers of phage production in lysogenic bacteria appear to have in common the characteristic of affecting the deoxyribonucleic (DNA) metabolism of the host cell. In the course of examining some antitumor compounds (kindly supplied by Dr. D. A. Karnofsky of the Sloan-Kettering Institute), the antibiotic streptonigrin, SN (Rao and Cullen, 1960), was found to be a potent inducer of phage formation (Levine and Borthwick, 1963a). Some of the properties of this compound and its effect on phage-host interactions are reported.

\section{MATERIALS AND METHODS}

Bacterial and bacteriophage strains. Phage P22, its hosts Salmonella typhimurium LT2 and $\mathrm{L} T 7$, derivatives of LT2 and LT7 lysogenic for P22, and a galactosenegative mutant of strain LT2 were employed in some of these experiments. In addition, Escherichia coli W3110 lysogenic for phage $\lambda$ and an indicator sensitive to $\lambda, E$. coli C600, were used. Both are substrains of the K12 strain of $E$. coli.

Media. The following media were utilized: L broth, nutrient agar, EMB galac-

\footnotetext{
${ }^{1}$ Supportcd by U.S.P.H.S. RG-9252R1.
}

tose agar, EMB lactose agar, soft agar for top layer, and buffered saline. The preparation of these media has been described (Levine, 1957). In addition, M-9 medium (3g $\mathrm{KH}_{2} \mathrm{PO}_{4}, 6 \mathrm{~g}$ anhydrous $\mathrm{Na}_{2} \mathrm{HPO}_{4}$, and $1 \mathrm{~g} \mathrm{NH} \mathrm{NH}_{4} \mathrm{Cl}$ in 1 liter of distilled $\mathrm{H}_{2} \mathrm{O}$ ) supplemented with $1.5 \%$ casamino acids, $0.4 \%$ glucose, $2 \mathrm{ml} 25 \% \mathrm{NaCl}$, and $2.5 \mathrm{ml} 1 M$ $\mathrm{MgSO}_{4}$ was used as a minimal medium.

Streptonigrin. As originally supplied by Dr. Karnofsky, SN was dissolved in acetone and phosphate buffer at $0.5 \mathrm{mg} / \mathrm{ml}$. More recent samples, obtained directly from the Chas. Pfizer Company, were in erystalline form. Stock solutions at $1 \mathrm{mg} / \mathrm{ml}$ in acetone are prepared. (The small amount of acetone present in the experimental cultures was shown to be without noticeable effects.)

Mitomycin $C(M C)$. MC stock solutions were made in distilled water at a concentration of $1 \mathrm{mg} / \mathrm{ml}$ (Levine, 1961).

Experimental procedures. Induction experiments with antibiotics wcre carricd out in the following way. Log phase lysogenic cells at concentrations of $1 \times 10^{8}$ cells $/ \mathrm{ml}$ were exposed to $\mathrm{SN}$ or $\mathrm{MC}$ in broth or minimal medium. After various times of incubation at $37^{\circ}$, samples were diluted in fresh medium and plated for detection of induction. The lysogenic LT7 and LT2 cells that were galactose positive ( $\left.\mathrm{gal}^{-1}\right)$ 
were plated on EMB galactose agar with a heavy inoculum of an LT2 $\mathrm{gal}^{-}$phagesensitive mutant. Induced cells lyse and form plaques scorable after 18 hours of incubation at $37^{\circ}$. After another 24 hours of incubation at room temperature, the surviving lysogenic $\mathrm{gal}^{+}$cells form dark colonies on the background of more slowly growing $\mathrm{gal}^{-}$cells and show a clear halo of lysis. Induction of $\lambda$ is detectable on EMB lactose agar since strain W3110 is lactose positive $\left(\mathrm{lac}^{+}\right)$and strain $\mathrm{C} 600$ is $\mathrm{lac}^{-}$.

Induction of lysogenic bacteria by ultraviolet light was accomplished by exposing 1 -ml samples of cells in minimal medium to a 15-watt Sylvania germicidal lamp for varying times at a distance of $50 \mathrm{~cm}$ from the samples. The treated cells were then plated on the appropriate EMB agar for detection of induction.

Unless otherwise noted, the percentage of induced cells or percentage of cells remaining lysogenic after a given treatment was

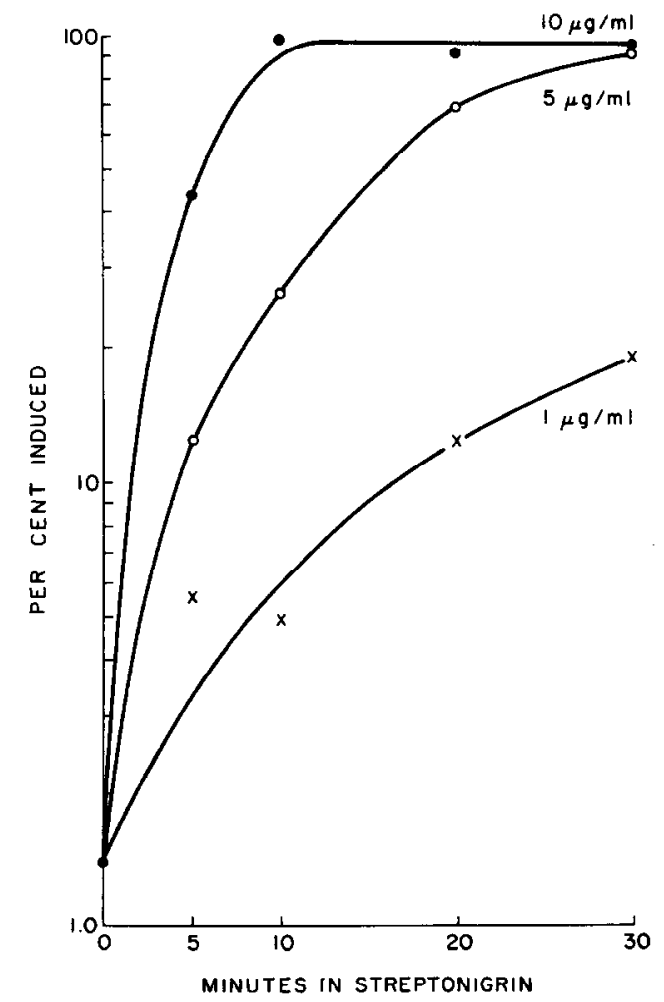

FIg. 1. Induction of S. typhimurium LT7(P22) after treatment with $10.0,5.0$, and $1.0 \mu \mathrm{g}$ SN per milliliter for varying time intervals. calculated from the number of plaques or colonies observed on the EMB agar plates, divided by the initial number of cells exposed to the treatment. Both the P22 and the $\lambda$ lysogenic systems showed on detection agar a spontaneous background of plaques around $1 \%$.

Protein, ribonucleic acid (RNA), DNA, and turbidity determinations were made as previously described (Levine, 1961). Other experimental methods will be described as needed.

\section{RESULTS}

Induction of Phage Production in Lysogenic Bacteria

Typical induction curves for strain LT7 (P22) treated with SN are shown in Fig. 1. Relatively short exposures, 10-15 minutes, to $10 \mu \mathrm{g}$ SN per milliliter achieved frequences of induction approaching $100 \%$; that is, practically every exposed cell produced phage. High levels of induction were found also after somewhat longer exposures to $5 \mu \mathrm{g} / \mathrm{ml}$. Treatment with $1 \mu \mathrm{g} / \mathrm{ml}$ SN also was found to induce, but lower induction levels are reached by the time lysis of induced cells occurs. Concentrations of SN greater than $10 \mu \mathrm{g} / \mathrm{ml}$ also result in induction, but a loss of infective centers occurs at these high concentrations. Figure 2 describes a survival curve of the lysogenic condition for strain LT7(P22) exposed to $10 \mu \mathrm{g}$ SN per milliliter. The log per cent of remaining lysogenic cells versus duration of exposure to the antibiotic plots as a straight line, indicating that the inducing action of SN proceeded with single-hit kinetics. Similar curves have been described for survival of lysogenic bacteria with other agents (Jacob and Wollman, 1953; Marcovich, 1956).

Escherichia coli $\mathrm{W} 3110(\lambda)$ was also induced by SN (Fig. 3), as was strain LT2 (P22).

Evidence for a Preferential Effect of SN on Bacterial DNA

Nonlysogenic strain LT7 bactcria growing logarithmically in minimal medium were exposed to $0.1,1.0$, and $10 \mu \mathrm{g} / \mathrm{ml} \mathrm{SN}$ at $37^{\circ}$ with aeration. Samples were removed 


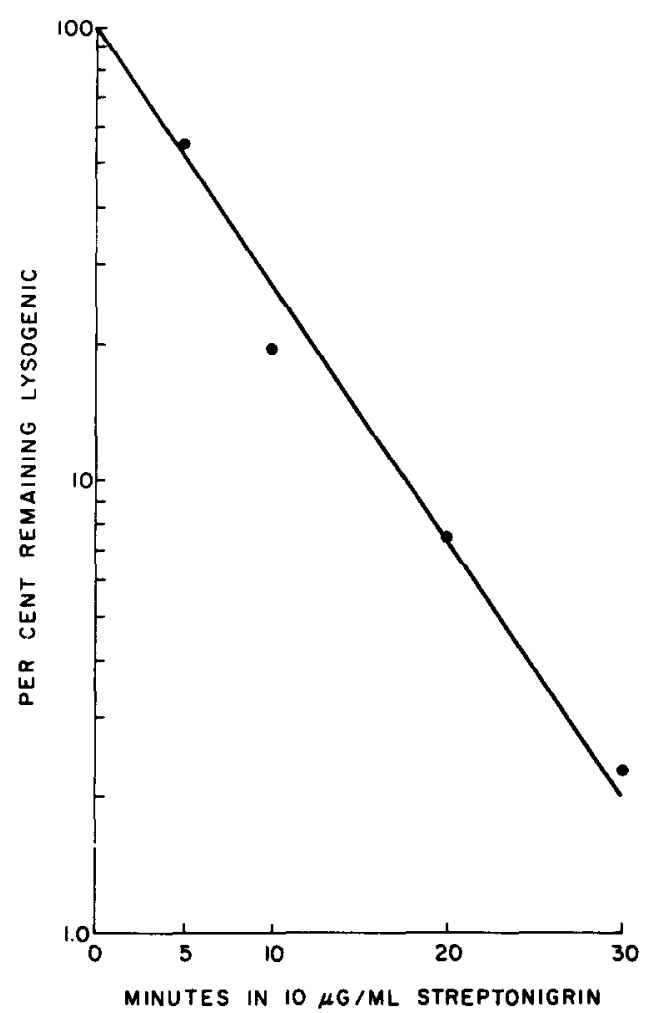

Fig. 2. Survival of S. typhimurium LT7(P22) cells after treatment with $10.0 \mu \mathrm{g}$ SN per milliliter for varying time intervals.

after 30,60 , and 90 minutes of treatment, washed two times in buffered saline, and resuspended in buffered saline. These samples were used for turbidity, DNA, RNA, and protein determinations (Table 1).

Net synthesis of bacterial DNA was almost completely inhibited in cells exposed to $10 \mu \mathrm{g}$ SN per milliliter. Synthesis of RNA and protein lagged somewhat behind control rates, but appreciable amounts were formed during the first 60 minutes of treatment. Synthesis of all components virtually ceased after 60 minutes at $10 \mu \mathrm{g}$ of the antibiotic per milliliter. More rapid inhibition of all components was found at higher concentrations. Similar results were obtained when cells were exposed to $\mathrm{SN}$ in broth.

The observed increase in turbidity of the $10 \mu \mathrm{g} / \mathrm{ml}$-treated culture was due to cell enlargement; snakelike forms were observed on microscopic examination. No evidence was found for cell multiplication as measured by increase in number of colony formers. In fact, the antibiotic is bactericidal. Less than $1 \%$ cells survived 60 minutes at $10 \mu \mathrm{g} / \mathrm{ml}$ in minimal medium and only $0.2 \%$ survived in broth. No marked inhibition of DNA synthesis was found with 1 or $0.1 \mu \mathrm{g} S \mathrm{~S}$ per milliliter. However, $1 \mu \mathrm{g} / \mathrm{ml}$ had some bactericidal action; only about $50 \%$ of the treated cells survived 60 minutes of exposure in minimal medium.

\section{Phage Production in SN-Treated Cells}

Infectious phage particles are produced in the presence of $\mathrm{SN}$ by both induced lysogenic and infected nonlysogenic cells. Yields of progeny particles within $50 \%$ of the yield obtained following ultraviolet light induction are observed when lysogenic cells of strains W3110 $(\lambda)$, LT7 (P22), and LT2(P22) are induced by $10 \mu \mathrm{g}$ SN per milliliter. Similarly, almost normal yields of active phages are obtained on infection of LT2 nonlysogenic cells with phage P22 in the presence of $10 \mu \mathrm{g} / \mathrm{ml} \mathrm{SN}$. The dura-

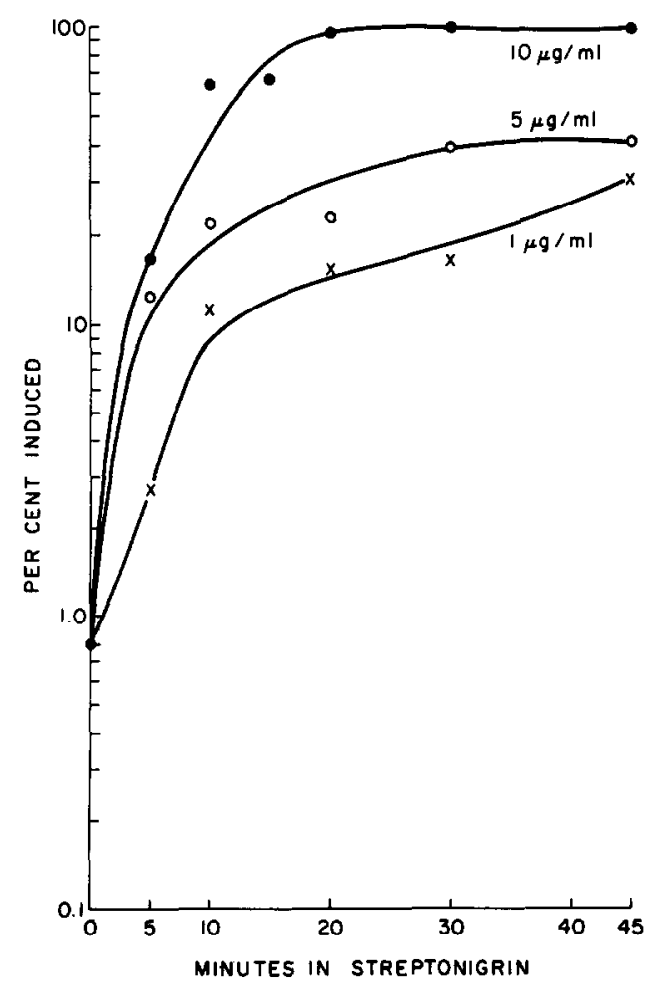

FIG. 3. Induction of $E$. coli W3110( $\lambda)$ after treatment with $10.0,5.0$, and $1.0 \mu \mathrm{g} \mathrm{SN}$ per milliliter for varying time intervals. 
tion of the latent period is the same as for untreated controls. It should be emphasized that phage is being produced in these cells under conditions which inhibit net synthesis of cellular DNA. Phage production is taken to indicate restoration of DNA synthesis in the presence of the inhibitor.

\section{Characterization of a SN-Resistant Lyso- genic Bacterium}

By repeated selection in broth and on petri plates supplemented with SN, a number of lines of strain LT7 have been isolated that show varying degrees of resistance to $10 \mu \mathrm{g}$ of the antibiotic per milliliter. One of these, line 74, lysogenic for phage P22 at the beginning of the selection procedure, will be described.

In $10 \mu \mathrm{g}$ SN per milliliter, line 74 is highly resistant to both the killing and inducing action of $\mathrm{SN}$; it multiplied at an exponential rate only slightly slower than control cells (Fig. 4). Over a 3-hour treatment period, the number of plaques on

\section{TABLE 1}

Preferential Inhibition of DNA Synthesis IN Salmonella typhimurium BY STREPTONIGRIN

\begin{tabular}{|c|c|c|c|c|c|}
\hline \multirow{2}{*}{$\begin{array}{l}\text { Concentra- } \\
\text { tion of SN } \\
(\mu \mathrm{g} / \mathrm{ml})\end{array}$} & \multirow{2}{*}{$\begin{array}{c}\text { Time of } \\
\text { incubation } \\
\text { (min.) }\end{array}$} & \multicolumn{4}{|c|}{ Per cent of amount at time 0} \\
\hline & & $\begin{array}{l}\text { Tur- } \\
\text { bidity }\end{array}$ & $\begin{array}{l}\text { Pro- } \\
\text { tein }\end{array}$ & $\mathrm{RNA}^{a}$ & DNA \\
\hline 0 & 0 & 100 & 100 & 100 & 100 \\
\hline 0 & 30 & 178 & 212 & 411 & 213 \\
\hline 0.1 & 30 & 200 & 227 & 394 & 211 \\
\hline 1.0 & 30 & 200 & 224 & 415 & 214 \\
\hline 10.0 & 30 & 205 & 176 & 279 & 111 \\
\hline 0 & 60 & 356 & 414 & 542 & 411 \\
\hline 0.1 & 60 & 336 & 366 & 556 & 460 \\
\hline 1.0 & 60 & 340 & 324 & 625 & 388 \\
\hline 10.0 & 60 & 311 & 275 & 489 & 120 \\
\hline 0 & 90 & 600 & 569 & 895 & 666 \\
\hline 0.1 & 90 & 578 & 539 & 854 & 731 \\
\hline 1.0 & 90 & 500 & 510 & 865 & 583 \\
\hline 10.0 & 90 & 311 & 293 & 521 & 115 \\
\hline
\end{tabular}

a In this and other experiments the RNA values at 30 minutes were unexpectedly but consistently too high. The cause of this finding is unknown.

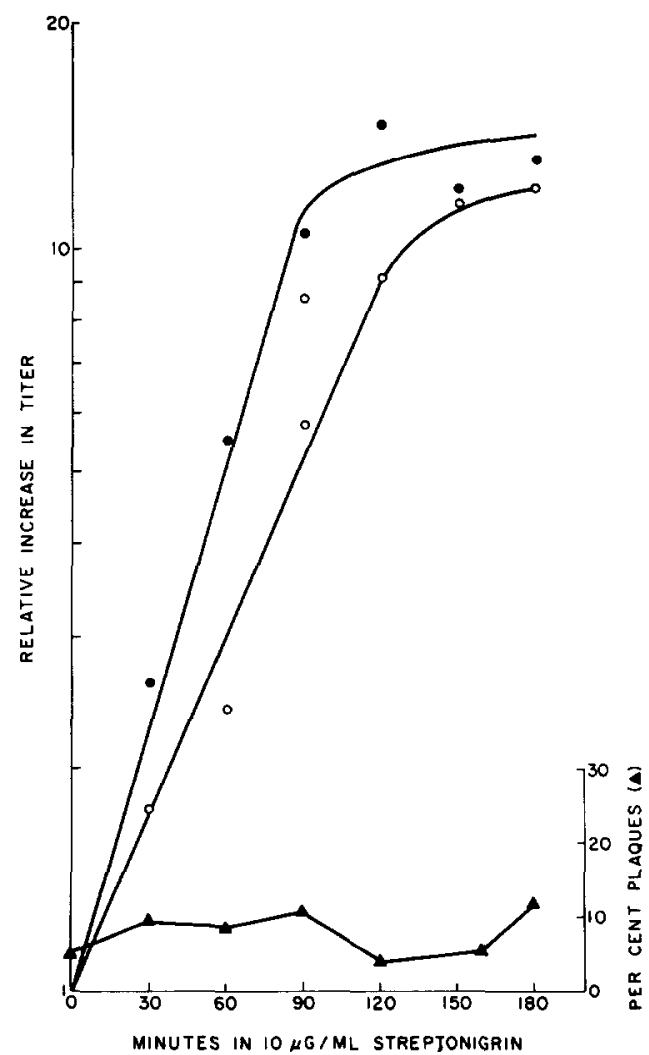

FIG. 4. Multiplication and induction of line 74 in $10 \mu \mathrm{g} \mathrm{SN}$ per milliliter. Line 74 growing in the absence of SN (๑). Line 74 growing in the presence of the antibiotic (O). Plaques in presence of SN (A).

EMB galactose test plates varied between 4 and $13 \%$ of the cell number, indicating that line 74 is only slightly inducible by $10 \mu \mathrm{g}$ SN per milliliter. Line 74 is not, however, completely resistant to the action of SN. When the concentration of the antibiotic was raised to $50 \mu \mathrm{g} / \mathrm{ml}, 50 \%$ of the treated cells were induced to produce phage after 30 minutes of exposure.

The question arises as to which component of the lysogenic complex, the host cell or the prophage, is responsible for the observed resistance of line 74 to $\mathrm{SN}$. To test the possibility that resistance is due to an alteration in the prophage, sensitive LT7 cells were lysogenized with phage derived from the prophage of line 74 . Resistance to induction by $\mathrm{SN}$ on the part of these new lysogenics, the cells of which had never 
before been exposed to SN, would be evidence for an alteration in the prophage. On the other hand, sensitivity to induction by $10 \mu \mathrm{g}$ SN per milliliter would be presumptive evidence that the alteration lay at the cellular level. On exposure to $10 \mu \mathrm{g} \mathrm{SN}$ per milliliter, these newly formed lysogenic bacteria show excellent induction of phage production, typical of that deseribed in Fig. 1 for wild-type LT7 (P22) cells. This result, therefore, suggests an alteration in the bacterial part of the complex of line 74. A direct test of this could be made if some cells of line 74 could be cured of prophage. No such nonlysogenic derivatives of line 74 have been found.

Susceptibility of line 74 to induction by agents other than SN has been examined to determine whether resistance to induction by SN necessarily carries with it crossresistances to other agents.

Line 74 showed no resistance to induction by ultraviolet light. The ultraviolet induction curve for line 74 was essentially the same as that of SN-sensitive LT7(P22) cells (Fig. 5).

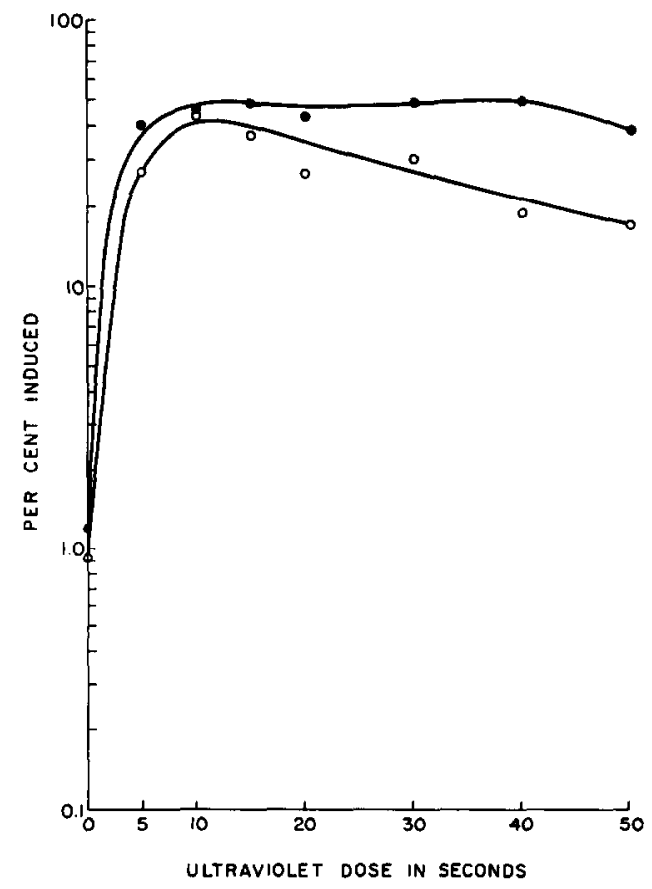

FIG. 5. Induction of S. typhimurium LT7(P22) $(\bullet)$ and line $74(O)$ by ultraviolet light.

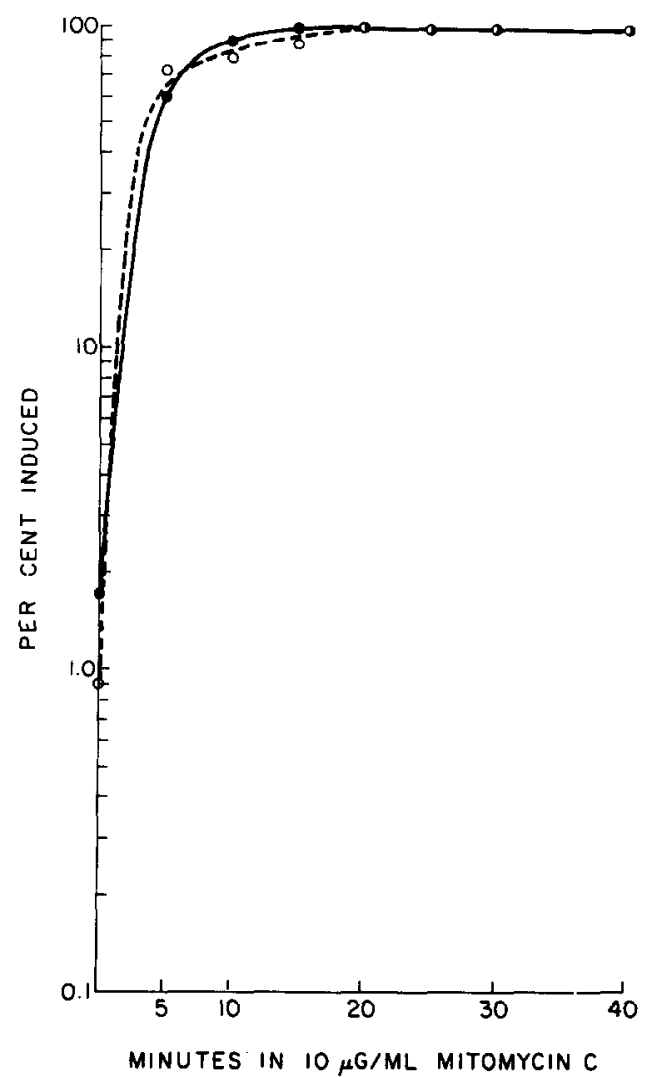

Fig. 6. Induction of S. typhimurium LT7(P22) $(\bullet)$ and line $74(O)$ by treatment with $10 \mu \mathrm{g}$ mitomycin $\mathrm{C}$ per milliliter for varying time intervals.

Of particular interest is a comparison of the inducing activity of another antibiotic mitomycin C (Otsuji et al., 1959; Levine, 1961) on line 74 and control LT7(P22) cells. MC and SN are similar in a number of ways (see discussion) and probably belong to the same family of compounds. A variety of results have been obtained. Line 74 shows no cross-resistance to the inducing action of $10 \mu \mathrm{g} / \mathrm{ml} \mathrm{MC}$; the induction curves of line 74 and SN-sensitive LT7 (P22) cells were found to be the same (Fig. 6). However, another line of LT7 (P22), independently selected as resistant to $\mathrm{SN}$, did show cross-resistance to MC.

\section{DISCUSSION}

SN may be added to the list of agents that induce lysogenic bacteria. In common 
with these agents, SN has a preferential deleterious action on bacterial DNA synthesis. Net DNA synthesis practically ceases in the presence of appropriate concentrations, whereas synthesis of protein and RNA proceeds. Other effects of SN on DNA are known: (1) SN causes degradation of bacterial DNA (Radding, 1963). (2) The antibiotic induces chromosome breaks in human leukocyte cultures (Cohen et al., 1963). (3) Increases in genetic recombination between appropriately marked $\mathrm{T} 4$, and between appropriately marked P22, phages are found when infected complexes are exposed to SN (Levine and Borthwick, 1963b).

The mechanism by which SN stimulates the induction of phage in lysogenic bacteria is unknown. The effect on bacterial DNA synthesis may upset the stable relationship between cell and prophage in such a way that vegetative replication of phage is no longer repressed. Of particular interest is the ability to form phage in the continued presence of the antibiotic. This finding suggests that phage DNA is synthesized by some system which is much less sensitive to SN than the host DNA synthesizing system. It further suggests that the apparent differential action of SN on bacterial and phage DNA metabolism may be a convenient way to study synthesis of DNA of temperate phages under conditions in which little or no synthesis of cellular DNA takes place (Radding, 1963).

$\mathrm{SN}$ and $\mathrm{MC}$ appear to be similar in a number of respects: (1) Both are quinones (Rao, personal communication). (2) Both selectively inhibit net DNA synthesis in bacterial cells (Shiba et al., 1959; Levine, 1961). (3) MC and SN initiate bacterial DNA degradation (Reich et al., 1961; Radding, 1963). (4) Both compounds induce lysogenic bacteria (Otsuji et al., 1959; Levine, 1961). (5) DNA synthesis, as measured by phage production, can be restored by phage infection or induction in the presence of either antibiotic (Sekiguchi and Takagi, 1959, 1960; Levine, 1961). On the other hand, therc are dissimilarities between these compounds: (1) Resistance to one antibiotic does not necessarily carry with it resistance to the other. (2) Exposure of mixedly infected bacteria to SN results in increases in the frequency of phage recombination. No such increases are found with MC (Levine, 1961; Levine and Borthwick, unpublished).

Lein et al. (1962), using the ability to induce $\lambda$ phage formation in $E$. coli $\mathrm{K} 12$ $(\lambda)$ bacteria as a method to screen for antitumor agents, also found induction with SN. Since inducers of phage formation act by virtue of their effect on the nucleic acid economy of lysogenic cells, the capacity to induce should also be a powerful tool for the detection of compounds that affect DNA metabolism.

\section{REFERENCES}

Cohen, M. M., Shaw, M. W., and Craig, A. G. (1963). The effects of streptonigrin on cultured human leukocytes. Proc. Nat. Acad. Sci. 50, 1624.

JACOB, F., and WollmaN, E. L. (1953). Induction of phage development in lysogenic bacteria. Cold Spring Harbor Symp. Quant. Biol, 18, 101-120.

Lein, J., Heinemann, B., and Gourevitch, A. (1962). Induction of lysogenic bacteria as a method of detecting potential antitumor agents. Nature 196, 783-784.

Levine, M. (1957). Mutation in the temperate phage P22 and lysogeny in Salmonella. Virology $3,22-41$.

Levine, M. (1961). Effect of mitomycin C on interactions between temperate phages and hacteria. Virology 13, 493-499.

Levine, M., and Borthwick, M. (1963a). Induction of phage production in lysogcnic bacteria with streptonigrin. Bacteriol. Proc., p. 153.

Levine, M., and Borthwick, M. (1963b). The action of streptonigrin on genetic recombination between bacteriophages. Proc. XI Intern. Congr. Genet. The Hague, Netherlands, in press.

Marcovich, H. (1956). Étude radiobiologique du systéme lysogène d'Escherichia coli K12. 1. Rayon X. Ann. Inst. Pasteur 90, 303-319.

Otsuji, N., Sekiguchi, M., Irjima, T., and Takagi, $Y$. (1959). Induction of phage formation in the lysogenic Escherichia coli $\mathrm{K} 12$ by mitomycin $C$. Nature 184, 1079-1080.

Radding, C. M. (1963). Uptake of tritiated thymidine by $\mathrm{K} 12(\lambda)$ induced by streptonigrin. Proc. $X I$ Intern. Congr. Genet. The Hague, Netherlands, in press.

Rao, K. V., and Cullen, W. P. (1960). Strepto- 
nigrin, an antitumor substance. I. Isolation and characterization. Antibiot. Ann., 950-953.

Reich, F., Shatkin, A. J., and Tatum, E. L. (1961). Bacteriocidal action of mitomycin $C$. Biochim. Biophys. Acta 53, 132-149.

Sekiguchi, M., and Takagi, Y. (1959). Synthesis of deoxyribonucleic acid by phage-infected Escherichia coli in the presence of mitomycin C. Nature 183, 1134-1135.
Sekiguchi, M., and Takagi, Y. (1960). Effect of mitomycin $C$ on the synthesis of bacterial and viral deoxyribonucleic acid. Biochim. Biophys. Acta 41, 434-443.

Shiba, S., Terawaki, A., Taguchi, T., and KaWaMATA, J. (1959). Selective inhibition of formation of deoxyribonucleic acid in Escherichia coli by mitomycin $C$. Nature $183,1056-1057$. 